\title{
O COMPROMISO COA EDUCACIÓN E COA ARTE
}

Silvia García González

Universidade de Vigo 

Afirmou Hans-Georg Gadamer ${ }^{1}$, na conferencia que impartiu a finais da década dos noventa sobre a educación, que só se pode aprender a través da conversa. É unha enunciación fermosa que nos invita a cuestionar os estereotipos sobre a educación. Formamos parte dun contexto que determina as nosas expectativas e desexos. A nosa educación prodúcese nun sistema educativo herdado e conformámonos con pasar dunha a outra etapa coma se fosen compartimentos estancos.

A estrutura das institucións educativas condiciona as relacións que se establecen entre os profesionais, pero non podemos seguir aceptando que na universidade se traballe sen ningún contacto coa educación primaria e secundaria. Non podemos conformarnos coa ausencia de redes de colaboración entre as distintas etapas e, por suposto, contamos co traballo dalgunhas asociacións no ámbito da educación plástica, pero son unha pequena minoría nun tristísimo panorama.

As institucións museísticas intentan tender pontes, desenvolvendo programas de colaboración para que os centros educativos non se limiten ao formato de visita escolar aos museos, pero falta moitísimo traballo, a medio e longo prazo, e non podemos conformarnos coa xustificación da falta de recursos.

Precisamos do compromiso para implicarnos no proceso de ensino-aprendizaxe.

Precisamos superar multitude de hábitos e estereotipos que fan que non nos cuestionemos o modo en que as clases continúan a parecer contedores que teñen como obxectivo manter os estudantes calados e sentados, mentres o profesor expón a súa lección «maxistral». Aínda se pensa que o modo de aprender é a repetición e a memorización. Fáltanos pedagoxía para difundir outras metodoloxías que favorecen a aprendizaxe, como o traballo por proxectos ou a investigación-acción.

\section{O COLECTIVO}

A filósofa Marina Garcés ${ }^{2}$ explica nunha entrevista que temos que aprender a dicir: Nós.

Fáltanos tamén cultura de traballo colectivo, e iso detéctase tamén no sistema educativo, porque non se promove o traballo cooperativo, ás veces por simple comodidade. Unha gran parte do profesorado considera que é máis sinxelo avaliar o traballo individual, e a falta de formación e motivación fai que cun argumento tan simple se desboten as metodoloxías que promoven o traballo colaborativo. 0 éxito individual é o obxectivo, o premio a unha carreira académica onde o importante é aprobar o exame e a nota media.

No ámbito concreto da arte, a situación non é mellor, porque o discurso oculto que se transmite nas facultades de arte é o discurso do elitismo, presupoñendo que no mellor dos mundos os mellores artistas van poder cobrar unha fortuna polas súas obras traballando coas mellores galerías. Segue a ser moi minoritario o enfoque social, o traballo co contexto; hai algúns exemplos, pero en cada facultade de Belas Artes é claramente unha minoría.

1 Gadamer, Hans-Georg (2000): La educación es educarse, Barcelona, Paidós, p. 10.

2 Garcés, Marina (2013): Entrevista en Para todos La 2. Programa emitido o 8 de abril de 2013 en La 2 de RTVE. 


\section{CONTEXTO}

E como podemos superar os condicionantes que nos impón a academia?

Por un lado, difundindo os proxectos que están activos e visibilizando o que queda por facer. No traballo co contexto, por exemplo, comprobamos que en Galicia a presenza da sociedade que non vive nas cidades é practicamente inexistente. Poderiamos citar o exemplo do Alga-lab ou o de Montenoso como dous dos colectivos que conseguiron visibilizar esa ausencia.

Se facemos memoria das nosas experiencias escolares, veremos que raramente se traballa co contexto, raramente se explora a aldea, o barrio. As experiencias limítanse en máis dun $90 \%$ a abrir un libro de texto, ler e subliñar, e facer exercicios repetitivos. Faise tamén algunha visita escolar a un museo, a unha fábrica ou a un teatro, pero son experiencias puntuais, que non adoitan estar ligadas ao traballo por proxectos.

\section{COMPROMISO}

Semella unha palabra envellecida, o compromiso.

No meu caso o compromiso forma parte da miña función docente e xestora, porque é necesario comprometerse co proceso de aprendizaxe, pero non podemos esquecer que a calidade no contexto académico tamén inclúe as funcións de información e orientación, intentando velar para que todos sexamos honestos no desempeño do noso traballo.

Aínda é preciso facer fincapé no compromiso coa aprendizaxe, por exemplo no contexto da formación do futuro profesorado. Nos seis cursos que levo impartindo clases no mestrado de formación do profesorado (a futuros profesores de Educación plástica e visual nos institutos), decateime de que existe e triunfa aínda o discurso familiar co que se consegue convencer aos estudantes que estudar unha oposición é a única saída digna á superación das etapas académicas previas. Se non se trata o tema do compromiso estaremos perpetuando un sistema que lle dá un título a moitas persoas que buscan un soldo fixo, e para non sentirse culpables pensan que o labor do profesorado é simplemente transmitir uns contidos (é bastante, argumentan).

Este fenómeno continúa porque a narrativa social sobre as oposicións segue a triunfar e moitos estudantes están plenamente convencidos de que, se aprobaron unha carreira, poden estudar un pouco máis para aprobar unha oposición, sen necesidade de sentir «necesariamente» unha vocación. Os institutos continúan cheos de persoas frustradas (profesorado e estudantes), e os profesionais motivados e implicados son as excepcións que conseguen que os estudantes descubran o pracer de aprender, algo que debería estar presente ao longo de toda a vida.

Precisamos de moito esforzo para conseguir que as persoas se decaten de que ser docente non é o resultado de «chapar» un temario, nin elaborar uns apuntamentos duradeiros, nin abrir un libro de texto pola páxina 30.

Temos unha enorme responsabilidade na formación das persoas, temos a responsabilidade de que sexan capaces de analizar o contexto en que viven con espírito crítico, que vexan que son capaces de conducir as súas vidas, que son capaces de aprender a aprender.

Desafortunadamente convivimos coa des-aprendizaxe día a día, porque os estudantes aprenderon na súa longa experiencia académica que o que se lles pide é estar calados, atentos e calados, convertidos en seres invisibles.

\section{A SEITA DO ROSA}

En moitos aspectos fomos para atrás. Existen estantes cheos de libros rosas en todas as librarías. Libros rosas que non existían hai 20 anos. 
Na educación plástica das escolas aínda se premia o ornamento, a decoración, a portada dun traballo feito con rotuladores de brillantina.

Moitas persoas cren que colorear é unha actividade relaxante e artística que se pode promover case ata a adolescencia, e algúns docentes preferirán esta idea de ornamento e a actividade de colorear antes que un debuxo no que se plasmou un mundo imaxinado. Ao estudante que plasma este mundo imaxinado pónselle pegas como: «É moi imaxinativo, pero non fai os debuxos limpos, sempre está todo un pouco engurrado, non sabe ser coidadoso».

No contexto español, os libros de María Acaso, algúns con títulos tan claros como La educación artística non son manualidades, están axudando a desmontar os prexuízos sobre a educación plástica, pero persisten os estereotipos que deixamos que se transmitan no contexto educativo, tamén no ámbito universitario.

Hai moitas estudantes que falan do seu futuro cunha humildade mal entendida, cando lles preguntas que queren facer no futuro afirman: «Bueno, se sae algo...».

A ambición profesional segue a ter connotacións positivas no caso de que sexas un home; no caso de que sexas muller a ambición profesional é censurable, acéptase que as estudantes son máis estudosas pero pídeselles que sigan sendo dóciles, caladas, "chaponas» sen abrir a boca, sen liderar, sen emprender.

É necesario repensar o traballo dos colectivos, é necesario promover o traballo cooperativo, repensar a autoría, promover a mirada crítica e cuestionar o éxito individual, que no campo da arte fai que perdure o estereotipo do artista-xenio-inspirado na procura dunha musa...

Temos tanto no que traballar, xa! 